\title{
Can uranyl complexes encapsulate to carbon nanotubes? A periodic DFT study
}

\author{
K SRINIVASU* and MAHESH SUNDARARAJAN* \\ Theoretical Chemistry Section, Bhabha Atomic Research Centre, Mumbai, Maharashtra 400 094, India \\ E-mail: ksvasu@barc.gov.in; smahesh@barc.gov.in
}

MS received 19 December 2016; revised 5 May 2017; accepted 12 May 2017

\begin{abstract}
Periodic density functional theory (DFT)-based calculations were carried out on a series of uranyl complexes encapsulated within single walled (SW)-CNT to understand their encapsulation affinities. We find that uranyl-aqua complex $\left(\left[\mathrm{UO}_{2}\left(\mathrm{H}_{2} \mathrm{O}\right)_{5}\right]^{2+}\right)$ binds stronger as compared to uranyl-hydroxo-complex $\left(\left[\mathrm{UO}_{2}(\mathrm{OH})_{4}\right]^{2-}\right)$ due to the variable overall charge of the complex. Further, binding affinities of uranyl formate complexes with different formate stoichiometries (1:1, 1:2 and 1:3) with SW-CNT are considered. Here again, due to variable charges, cationic mono-'formate-uranyl $\left(\left[\mathrm{UO}_{2}(\mathrm{FM})\left(\mathrm{H}_{2} \mathrm{O}\right)_{3}\right]^{1+}\right)$ complex binds stronger as compared to anionic tri-formate uranyl $\left(\left[\mathrm{UO}_{2}(\mathrm{FM})_{3}\right]^{1-}\right)$. Further, due to the very weak binding commonly found in $\left[\mathrm{UO}_{2}(\mathrm{FM})_{3}\right]^{1-}$ to CNT, the tubular ends of SW-CNT are sealed with functionalized $\mathrm{C}_{36}$ fullerene. The binding affinity of uranyl complex is not improved when $\mathrm{C}_{36}$ fullerene is used to seal to the SW-CNT as compared to its unsealed counterpart. However, upon functionalizing (at the hub carbon) the $\mathrm{C}_{36}$ cork, the binding affinity of $\left[\mathrm{UO}_{2}(\mathrm{FM})_{3}\right]^{1-}$ is larger inside the CNT due to favorable hydrogen bonding interactions with the uranyl oxygens. Our findings are consistent with the experimental observations which will help to design novel nanomaterials for nuclear waste management processes.
\end{abstract}

Keywords. Carbon nanotubes; density functional theory; uranyl encapsulation; uranyl functionalization.

\section{Introduction}

Presently, the energy demands are exponentially increasing, thus alternative energy resources such as nuclear energy are unavoidable with the penalty of safe handling of small volumes of nuclear wastes. ${ }^{1,2}$ Due to the apparent toxic and radioactive nature of the heavy metal ions, the design of novel materials for waste management is mandatory. ${ }^{3,4}$ Since the discovery of fullerenes, ${ }^{5}$ several new fields have emerged till date in science and technology. ${ }^{6,7}$ Carbon based nanomaterials are applied to targeted drug delivery systems, cancer therapy, hydrogen storage, water purification and photo catalysis to name a few. ${ }^{8-11}$ Recently, Belloni et al. ${ }^{12}$ reviewed on the possibility of using carbon nanotubes in the field of nuclear waste management (NWM) processes.

Although many extractants are known till date, ${ }^{13-16}$ attempts are being made towards the possible use of carbon nanotubes for the selective extraction or binding of radionuclides. Furthermore, wide varieties of carbon nanomaterials such as graphenes, activated carbon, mesoporous materials, multi-walled carbon nanotubes are now presently being tested as potential candidates for the binding of actinides, at least at the laboratory

\footnotetext{
*For correspondence
}

level. ${ }^{17-25}$ However, due to apparent solubility issues of pure carbon nanotubes, several attempts are made to improve the solubility of CNT through chemical functionalization. ${ }^{26,27}$ Of the several known carbon materials, CNT functionalized with several organic groups are known to be one of the promising carbon materials for the selective extraction of actinides. ${ }^{28-33}$

In conjunction with experimental work, a number of in silico studies are carried out to gain insights towards the binding behavior of radionuclides with CNT at the molecular level. ${ }^{34-39}$ Particularly, density functional theory (DFT) based calculations are popularly used to understand the selective binding of radionuclides. A number of studies are reported on graphene oxide nanosheets by Wu et al., ${ }^{34,35}$ towards understanding the binding preferences of actinyl ions. We have designed novel nano-materials through covalent and non-covalent functionalization of single walled (SW) CNT for the efficient binding of uranyl. ${ }^{37-39}$ Although the covalent binding of actinides at the functionalized site leads to very strong binding affinities, the subsequent release of actinides from the functionalized site is unfavorable. Thus, attempts are made towards non-covalent binding of actinides. In this regard, non-covalent functionalization of SW-CNT with cucurbituril supramolecule 
has found that uranyl binding is stronger as compared to unfunctionalized counterpart. ${ }^{39}$ Recently, Luksirikul et al. ${ }^{30}$ have investigated the $\mathrm{pH}$-triggered release of uranyl and copper acetate upon functionalization with $\mathrm{SW}-\mathrm{CNT}$. Here, the functionalized $\mathrm{C}_{60}$ fullerene was used as corks which can be unplugged or plugged by tuning the $\mathrm{pH}$. Thus, the safe release of actinides can be controlled efficiently. However, the binding mechanism of uranyl to SW-CNT is largely unexplored at the molecular level. As uranyl acetate exists in different stoichiometry, their speciation inside SW-CNT is largely unknown.

In this paper, structures and binding affinities of several uranyl complexes with SW-CNT are carried out using periodic DFT based calculations. A series of different uranyl complexes with varying ligand environment and with differing charge are chosen in this study. An attempt was made to improve the binding affinities of uranyl through functionalized fullerene $\left(\mathrm{C}_{36}\right)$ as removable corks with SW-CNT at the molecular level.

\section{Computational details}

\subsection{Choice of method}

Geometry optimizations were performed with periodic DFT calculations using the projector augmented wave (PAW) ${ }^{40,41}$ potentials as it is implemented in the Vienna ab initio Simulation Package (VASP). ${ }^{42,43}$ Plane-wave basis sets with a kinetic energy cut-off of $550 \mathrm{eV}$ have been used to expand the Kohn-Sham equations for the valance electrons. Generalized Gradient Approximation (GGA) of Perdew-Burke-Ernzerhof $(\mathrm{PBE})^{44}$ has been used to treat the exchange-correlation energy density functional. Energy cut-off for the electronic self-consistent field iterations is set to $1 \times 10^{-6} \mathrm{eV}$. The valence states of $U\left(5 f^{3} 6 d^{2} 6 p^{6} 7 s^{2}\right), C\left(2 s^{2} 2 p^{2}\right), O\left(2 s^{2} 2 p^{4}\right)$ and $\mathrm{H}\left(1 s^{1}\right)$ were considered for the construction of the PAW potentials. Sufficient vacuum $(\sim 15 \AA)$ has been considered along the non-periodic directions for the CNT calculations.
Isolated systems were optimized in a cubic cell of dimension $25 \AA \times 25 \AA \times 25 \AA$. For the one-dimensional systems, both unit cell and atomic positions were relaxed at constant volume until the maximum Hellmann-Feynman force on each atom is less than $0.01 \mathrm{eV}^{-1}$. Automatically generated Gammacentered $1 \times 1 \times 3$ Monkhorst-Pack set of k-points were used to sample the Brillouin zone. ${ }^{45}$ The atomic charges were calculated through the Bader charge density analysis. ${ }^{46,47}$ The graphical software VESTA ${ }^{48}$ has been used for generating the reported periodic structures. This computational technique was used by us to model several periodic systems and the predictions are exceptionally encouraging with experimental data. ${ }^{49,50}$ For all charged systems, the monopole corrections to the energies have been taken into account.

\subsection{Choice of models}

A wide range of uranyl complexes with differing coordination number and ligands at the equatorial plane of the metal ion were considered and investigated here. Uranyl hydroxo species $\left(\left[\mathrm{UO}_{2}(\mathrm{OH})_{4}\right]^{2-}\right)$, uranyl aqua complex $\left(\left[\mathrm{UO}_{2}\left(\mathrm{H}_{2} \mathrm{O}\right)_{5}\right]^{2+}\right)$ and three uranyl formates $\left(\left[\mathrm{UO}_{2}(\mathrm{FM})_{3}\right]^{1-}\right.$, $\left[\mathrm{UO}_{2}(\mathrm{FM})_{2}\left(\mathrm{H}_{2} \mathrm{O}\right)\right]^{0}$ and $\left.\left[\mathrm{UO}_{2}(\mathrm{FM})\left(\mathrm{H}_{2} \mathrm{O}\right)_{3}\right]^{1+}\right)$ were studied. Arm-chair $[(7,7),(8,8)$ and $(9,9)]$ SW-CNT with differing diameters at four unit cell lengths were investigated here. We find that arm-chair $(9,9)$ is large enough to encapsulate all the uranyl complexes investigated here.

\section{Results and Discussion}

The optimized structures of bare and encapsulated uranyl at the DFT level are shown in Figures 1 and 2. Prior to encapsulation, let us glance through the optimized structures of bare uranyl complexes against experimental data. ${ }^{51-55}$ The calculated $\mathrm{U}=\mathrm{O}_{\mathrm{yl}}$ bond lengths are excellently reproduced for the two cationic complexes (within $0.02 \AA$ ) as compared to the two anionic complexes. The computed bond length for $\mathrm{U}=\mathrm{O}_{\mathrm{yl}}$ of $\left[\mathrm{UO}_{2}(\mathrm{OH})_{4}\right]^{2-}$ complex is estimated by

\begin{tabular}{|l|c|c|c|c|c|}
\hline & {$\left[\mathrm{UO}_{2}(\mathrm{OH})_{4}\right]^{2-}$} & {$\left[\mathrm{UO}_{2}(\mathrm{FM})_{3}\right]^{1-}$} & {$\left[\mathrm{UO}_{2}(\mathrm{FM})_{2}\left(\mathrm{H}_{2} \mathrm{O}_{2}\right]^{0}\right.$} & {$\left[\mathrm{UO}_{2}(\mathrm{FM})\left(\mathrm{H}_{2} \mathrm{O}_{3}\right]^{1+}\right.$} & {$\left[\mathrm{UO}_{2}\left(\mathrm{H}_{2} \mathrm{O}\right)_{5}\right]^{2+}$} \\
\hline & & & &
\end{tabular}

${ }^{\mathrm{a}}$ Values in brackets are the experimental data.

${ }^{\mathrm{b}} \mathrm{X}=\mathrm{OH}, \mathrm{FM}$

Figure 1. Optimized structures and bond lengths (in $\AA$ ) of bare uranyl complexes ${ }^{\mathrm{a}, \mathrm{b}}$. 


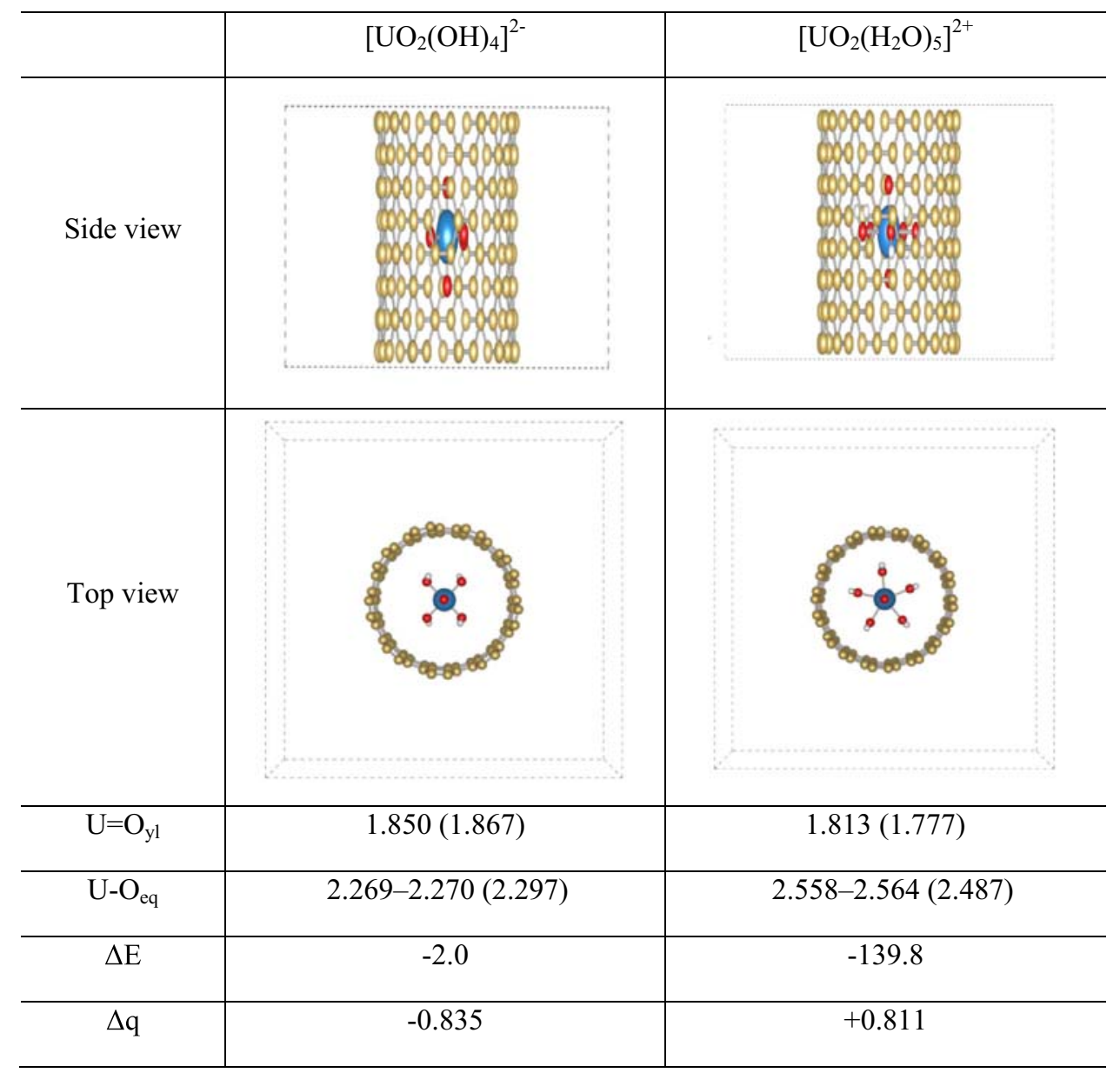

${ }^{\mathrm{a}}$ Values in brackets are for the corresponding isolated uranyl complexes.

Figure 2. Optimized structures (bond lengths in $\AA$ ), binding energies ( $\Delta \mathrm{E}$ in $\mathrm{kcal} \mathrm{mol}^{-1}$ ) and net charge transfer $(\Delta q$ in a.u) of uranyl hydroxide and uranyl aqua complexes encapsulated to SW-CNT.

$0.04 \AA$ as compared to experimental data. For the monocationic and mono-anionic complex, this overestimation is less (within $0.02 \AA$ ). As far as U-X bond lengths are concerned, the computed values are fairly reproduced within $0.05 \AA$ with the experimental values. Finally, the predicted $\mathrm{U}-\mathrm{O}_{\mathrm{H} 2 \mathrm{O}}$ are overestimated by 0.05 to $0.15 \AA$. Nevertheless, we are mainly interested in the change in bond lengths upon encapsulation with SW-CNT, thus, the trends are more vital than the absolute bond lengths.

\subsection{Structures and binding affinities of $\left[\mathrm{UO}_{2}(\mathrm{OH})_{4}\right]^{2-}$ and $\left[\mathrm{U} \mathrm{O}_{2}\left(\mathrm{H}_{2} \mathrm{O}\right)_{5}\right]^{2+}$ species}

Uranyl complexes in different orientations such as either $\mathrm{UO}_{2}$ moiety is parallel to inner walls or perpendicular to the inner walls of SW-CNT are considered in this study. We note that $\mathrm{UO}_{2}$ moiety parallel to the inner walls is relatively more stable (by more than $10 \mathrm{kcal}$ $\mathrm{mol}^{-1}$ for $\left.\left[\mathrm{UO}_{2}\left(\mathrm{H}_{2} \mathrm{O}\right)_{5}\right]^{2+}\right)$ as compared to the other orientation. Thus, we considered only parallel orientation hereafter. Upon encapsulation of anionic $\left[\mathrm{UO}_{2}(\mathrm{OH})_{4}\right]^{2-}$ to SW-CNT, the $\mathrm{U}=\mathrm{O}_{\mathrm{yl}}$ and $\mathrm{U}-\mathrm{O}_{\mathrm{eq}}$ bond lengths of the anionic species are shortened (Figure 2). For the cationic $\left[\mathrm{UO}_{2}\left(\mathrm{H}_{2} \mathrm{O}\right)_{5}\right]^{2+}$ complex, both $\mathrm{U}=\mathrm{O}_{\mathrm{yl}}$ and $\mathrm{U}-\mathrm{O}_{-\mathrm{eq}}$ bond lengths are elongated upon encapsulation.

Further, as far as binding energies of uranyl complexes to SW-CNT are concerned, we predict that cationic complex is strongly bound $\left(-140 \mathrm{kcal} \mathrm{mol}^{-1}\right)$ as compared to the anionic complex $\left(-2 \mathrm{kcal} \mathrm{mol}^{-1}\right)$. These variations are expected as SW-CNT can be considered as strong nucleophiles which can bind electrophilic complexes such as $\left[\mathrm{UO}_{2}\left(\mathrm{H}_{2} \mathrm{O}\right)_{5}\right]^{2+}$ stronger as compared to anionic $\left[\mathrm{UO}_{2}(\mathrm{OH})_{4}\right]^{2-}$. The differential binding affinities of the two complexes can be correlated to the extent of charge transfer from the uranyl complex to SW-CNT. In the $\left[\mathrm{UO}_{2}(\mathrm{OH})_{4}\right]^{2-}$ complex, the negative charge is transferred $\left(-0.472 \mathrm{e}^{-}\right)$from uranyl to SW-CNT, whereas for the $\left[\mathrm{UO}_{2}\left(\mathrm{H}_{2} \mathrm{O}\right)_{5}\right]^{2+}$ complex, the positive charge of uranyl is reduced through charge transfer $\left(+0.735 \mathrm{e}^{-}\right)$from SW-CNT. 


\begin{tabular}{|c|c|c|c|}
\hline & {$\left[\mathrm{UO}_{2}(\mathrm{FM})\left(\mathrm{H}_{2} \mathrm{O}\right)_{3}\right]^{1+}$} & {$\left[\mathrm{UO}_{2}(\mathrm{FM})_{2}\left(\mathrm{H}_{2} \mathrm{O}\right)_{2}\right]^{0}$} & {$\left[\mathrm{UO}_{2}(\mathrm{FM})_{3}\right]^{1-}$} \\
\hline $\begin{array}{l}\text { Side } \\
\text { view }\end{array}$ & 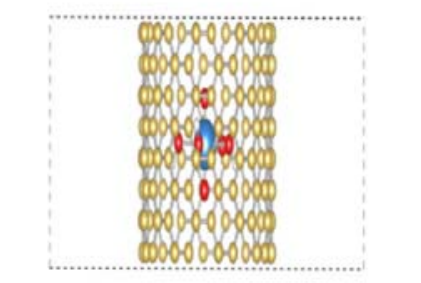 & 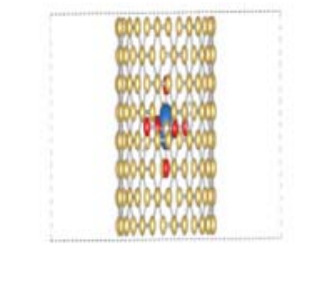 & 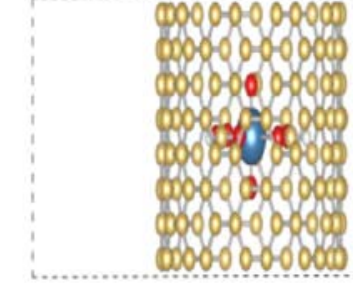 \\
\hline $\begin{array}{l}\text { Top } \\
\text { view }\end{array}$ & & & \\
\hline $\mathrm{U}=\mathrm{O}_{\mathrm{yl}}$ & $1.811(1.792)$ & $1.798(1.800)$ & $1.807(1.807)$ \\
\hline $\mathrm{U}-\mathrm{O}_{\mathrm{FM}}$ & $2.432(2.381)$ & $2.485(2.496)$ & $2.498(2.522)$ \\
\hline $\mathrm{U}-\mathrm{O}_{\mathrm{H} 2 \mathrm{O}}$ & $2.512-2.538(2.507-2.521)$ & $2.565(2.597)$ & - \\
\hline$\Delta \mathrm{E}$ & -53.1 & +0.7 & +25.3 \\
\hline$\Delta q$ & +0.456 & +0.104 & -0.022 \\
\hline
\end{tabular}

${ }^{a}$ Values in brackets are for the corresponding isolated uranyl complexes.

Figure 3. Optimized structures (bond lengths in $\AA$ ), binding energies $\left(\Delta \mathrm{E}\right.$ in $\mathrm{kcal} \mathrm{mol}^{-1}$ ) and net charge transfer $(\Delta \mathrm{q}$ in a.u) of uranyl formates encapsulated to SW-CNT.

\subsection{Structures and binding affinities of uranyl formates}

Experimental studies on uranyl acetates with SW-CNT suggest that the complex binding is unfavorable. ${ }^{30}$ The exact speciation is not known as uranyl acetate can exist in three different stoichiometric forms. The structures and binding affinities of three uranyl formats, $\left[\mathrm{UO}_{2}(\mathrm{FM})\left(\mathrm{H}_{2} \mathrm{O}\right)_{3}\right]^{1+},\left[\mathrm{UO}_{2}(\mathrm{FM})_{2}\left(\mathrm{H}_{2} \mathrm{O}\right)_{2}\right]^{0}$ and $\left[\mathrm{UO}_{2}(\mathrm{FM})_{3}\right]^{1-}$ with SW-CNT, are calculated. For computational ease, uranyl formates are considered instead of uranyl acetates.

In all three encapsulated complexes, the $\mathrm{U}=\mathrm{O}_{\mathrm{yl}}$ bond length decreases from $\left[\mathrm{UO}_{2}(\mathrm{FM})\left(\mathrm{H}_{2} \mathrm{O}\right)_{3}\right]^{1+}$ to $\left[\mathrm{UO}_{2}(\mathrm{FM})_{3}\right]^{1-}$ (Figure 3 ). However, for the bare uranyl formate complexes, both $\mathrm{U}=\mathrm{O}_{\mathrm{yl}}$ and $\mathrm{U}-\mathrm{O}_{\mathrm{FM}}$ bond lengths increase with increasing negative charge of the complex. Further, the extent of geometric variation upon encapsulation is less, as we go from cationic $\left[\mathrm{UO}_{2}(\mathrm{FM})\left(\mathrm{H}_{2} \mathrm{O}\right)_{3}\right]^{1+}$ to anionic $\left[\mathrm{UO}_{2}(\mathrm{FM})_{3}\right]^{1-} \mathrm{com}-$ plexes. As far as the binding affinities are concerned, the $\left[\mathrm{UO}_{2}(\mathrm{FM})\left(\mathrm{H}_{2} \mathrm{O}\right)_{3}\right]^{1+}$ binds strongest (more than -53 $\left.\mathrm{kcal} \mathrm{mol}{ }^{-1}\right)$, whereas the binding of $\left[\mathrm{UO}_{2}(\mathrm{FM})_{3}\right]^{1-}$ is unfavorable to SW-CNT (more than $+23 \mathrm{kcal} \mathrm{mol}^{-1}$ ). However, the binding affinity of $\left[\mathrm{UO}_{2}(\mathrm{FM})_{2}\left(\mathrm{H}_{2} \mathrm{O}\right)_{2}\right]^{0}$ is larger as compared to $\left[\mathrm{UO}_{2}(\mathrm{FM})_{3}\right]^{1-}$, and smaller as compared to $\left[\mathrm{UO}_{2}(\mathrm{FM})\left(\mathrm{H}_{2} \mathrm{O}\right)_{3}\right]^{1+}$. These variations in binding affinities can again be correlated with the extent of charge transfer $(\Delta \mathrm{q}$, Figure 3$)$. As expected, for the cationic $\left[\mathrm{UO}_{2}(\mathrm{FM})\left(\mathrm{H}_{2} \mathrm{O}\right)_{3}\right]^{1+}$ complex, positive charge of the complex is neutralized by SW-CNT leading to favorable binding, whereas for the negatively charged $\left[\mathrm{UO}_{2}(\mathrm{FM})_{3}\right]^{1-}$ complex, the extent of charge transfer is very less, thus unfavorable binding is clearly seen.

Thus, molecular level understanding of encapsulation of various uranyl complexes to SW-CNT helps us to reveal many insights such as the charge transfer which stabilizes the adduct formation. In the next section, we show how to stabilize even the unfavorable 

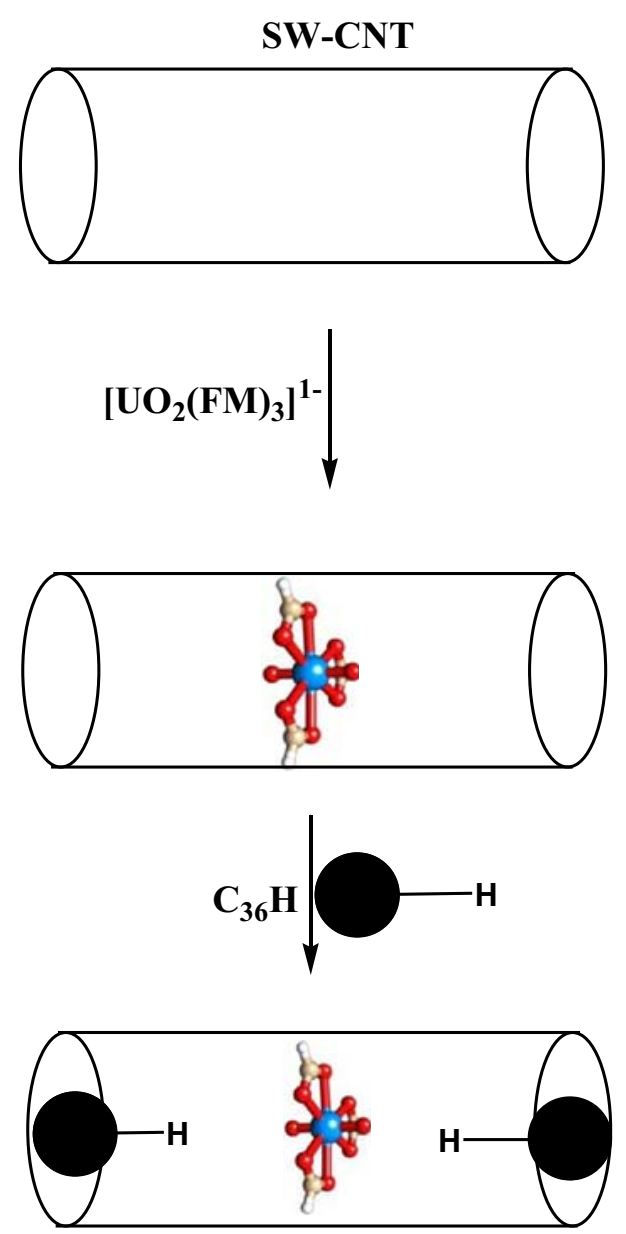

Scheme 1. Proposed favorable binding mechanism of encapsulated $\left[\mathrm{UO}_{2}(\mathrm{FM})_{3}\right]^{1-}$ with SW-CNT corked with functionalized $\mathrm{C}_{36}$ fullerene.

anionic uranyl complex such as $\left[\mathrm{UO}_{2}(\mathrm{FM})_{3}\right]^{1-}$ to $\mathrm{SW}$ CNT through the on-off-cork mechanism, as observed by Luksirikul et al. ${ }^{30}$ (Scheme 1).

\subsection{Corking the SW-CNT with fullerene}

In the experimental study of Luksirikul et al., ${ }^{30}$ a dimethyl amine-functionalized $\mathrm{C}_{60}$ fullerene was used to cork the SW-CNT. For computational efficiency, we use a $\mathrm{C}_{36}$ fullerene which can be used as cork to $(10,10)$ SW-CNT. SW-CNT super cell with 216 carbon atoms has been considered and the optimized cell parameter for the $\mathrm{CNT}$ is found to be $14.83 \AA$ with a $\mathrm{C}-\mathrm{C}$ bond length of $1.421 \AA$. Calculated insertion energy of $\mathrm{C}_{36}$ into SW-CNT is found to be energetically unfavorable $\left(+5.2 \mathrm{kcal} \mathrm{mol}^{-1}\right)$. Further, the $\mathrm{C}_{36}$ unit is functionalized by protonating the hub-carbon of the $\mathrm{C}_{36}$ unit to mimic the experimental functionalization. Of the several carbon centers in fullerenes, the choice of protonation at the Hub carbon is already well established. ${ }^{56}$ In this case, the $\mathrm{C}_{36}$ functionalized with two protons is found to have favorable encapsulation with $-221.8 \mathrm{kcal} \mathrm{mol}^{-1}$ of binding energy. Within this super cell, we placed one $\left[\mathrm{UO}_{2}(\mathrm{FM})_{3}\right]^{1-}$ and one $\mathrm{C}_{36}$ fullerene as shown in Figure 4.

As expected, the initial binding of $\left[\mathrm{UO}_{2}(\mathrm{FM})_{3}\right]^{1-}$ to SW-CNT is unfavorable by $23.8 \mathrm{kcal} \mathrm{mol}^{-1}$. Further, upon using the $\mathrm{C}_{36}$ cork (without functionalizing), the binding is unfavorable by $32.8 \mathrm{kcal} \mathrm{mol}^{-1}$. However, if we use the functionalized $\mathrm{C}_{36}$ cork to block the cap of SW-CNT, the binding becomes favorable by -76.7 $\mathrm{kcal} \mathrm{mol}^{-1}$ (Figure 4). The favorable binding is largely due to the hydrogen bonding interaction between the uranyl oxygen with the proton $(\sim 2.6 \AA)$ attached to the hub-carbon of $\mathrm{C}_{36}$ fullerene. Thus, upon deprotonation, the cork can be removed and we can isolate the $\left[\mathrm{UO}_{2}(\mathrm{FM})_{3}\right]^{1-}$ species very effectively. ${ }^{30}$

\subsection{Relevance to NWM processes}

One of the main challenges in the back-end of the nuclear fuel cycle is the selective removal of heavy metal ions and fission products. A dominant amount of work is focused on the separation of minor actinides from lanthanides. ${ }^{57}$ On the other hand, designing novel materials using CNT is one of the on-going strategies in NWM processes. ${ }^{12}$ Due to apparent solubility issues, functionalizing CNT with ionizable residues and with supramolecules can greatly enhance the solubility and binding affinities of heavy metal ions. ${ }^{37-39}$ However, the unbinding process of heavy metal ions at the functionalized sites of carbon nanotubes (CNT) is difficult due to very strong binding affinities. Thus, the non-covalent functionalization of supramolecules with CNT is proposed as an alternative. DFT based prediction on model system has provided many new insights into the experimental predictions.

The SW-CNT can bind cationic complexes very strongly as compared to anionic complexes due to the nucleophilic nature of SW-CNT. The anionic complexes such as $\left[\mathrm{UO}_{2}(\mathrm{FM})_{3}\right]^{1-}$ can be stabilized through the use of functionalized fullerene as removable cork. The cork can be attached or detached to the SW-CNT by tuning $\mathrm{pH}$ of the functionalized site of the fullerene. At low $\mathrm{pH}$, the functionalized site is expected to be protonated which will stabilize the anionic complex through hydrogen bonding. Thus, upon changing the $\mathrm{pH}$, deprotonation occurs at the functionalized fullerene site which nullifies the hydrogen bonding, and the cork is removed from SW-CNT. Based on this strategy, the radionuclide can be easily disposed to the desired location. 


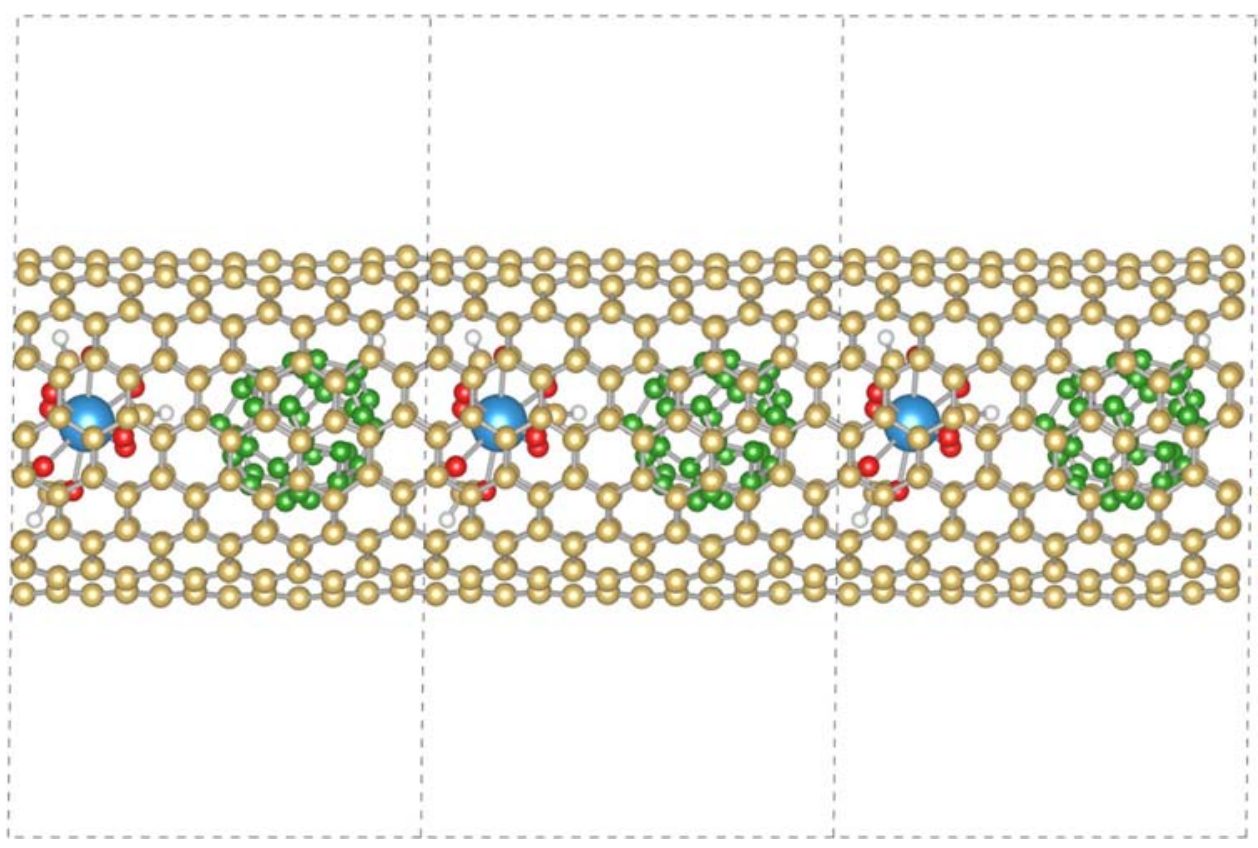

Figure 4. Optimized structure of encapsulated $\left[\mathrm{UO}_{2}(\mathrm{FM})_{3}\right]^{1-}$ with SW-CNT corked with functionalized $\mathrm{C}_{36}$ fullerene.

\section{Conclusions}

Understanding the speciation of toxic radionuclides such as uranyl complexes can be extremely important to design novel extraction by selective binding of harmful radionuclides. Our quantum chemical calculations based predictions of several uranyl complexes with SWCNT are as follows: (a) Cationic uranyl complexes such as $\left[\mathrm{UO}_{2}\left(\mathrm{H}_{2} \mathrm{O}\right)_{5}\right]^{2+}$ bind stronger as compared to their anionic counter-parts, $\left[\mathrm{UO}_{2}(\mathrm{OH})_{4}\right]^{2-}$, with SWCNT. The stronger binding is typically due to the extent of charge transfer from SW-CNT to uranyl. (b) The anionic complex such as $\left[\mathrm{UO}_{2}(\mathrm{FM})_{3}\right]^{1-}$ can be stabilized inside SW-CNT through the use of removable cork which can stabilize the anionic complex through hydrogen bonding. It should be noted that the removable cork (protonated at the hub carbon of $\mathrm{C}_{36}$ ) is necessary for favorable binding affinities of uranyl complexes with SW-CNT.

\section{Acknowledgements}

We thank BARC computer center for providing the high performance parallel computing facility (Adhya and Ajeya Systems).

\section{References}

1. Katz J J, Morss L R and Seaborg G T 1986 In The Chemistry of the Actinide Elements $2^{\text {nd }}$ edn. (London: Chapman and Hall)
2. Taylor D M and Taylor S K 1997 Environmental uranium and human health Rev. Environ. Health 12147

3. Lieberman J A and Belter W G 1967 Waste management and environmental espects of nuclear power Environ. Sci. Technol. 1466

4. Hileman B 1982 Nuclear waste disposal Environ. Sci. Technol. 16 271A

5. Kroto H W, Heath J R, Obrien S C, Curl R F and Smalley R E 1985 C $_{60}$ : Buckminsterfullerene Nature 318 162

6. Iijima S 1991 Helical microtubules of graphitic carbon Nature 35456

7. Baughman R H, Zakhidov A A and de Heer W A 2002 Carbon Nanotubes-the Route Toward Applications Science 297787

8. Cheng H M, Yang Q H and Liu C 2001 Hydrogen storage in carbon nanotubes Carbon 391447

9. Bianco A, Kostarelos K and Prato M 2005 Applications of carbon nanotubes in drug delivery Curr. Opin. Chem. Biol. 9674

10. Yu Y, Yu J C, Yu J G, Kwok Y C, Che Y K, Zhao J C, Ding L, Ge W K and Wong P K 2005 Enhancement of photocatalytic activity of mesoporous $\mathrm{TiO}_{2}$ by using carbon nanotubes App. Catalysis A 289186

11. Shi Kam N W, O'Connell M, Wisdom J A and Dai H 2005 Carbon nanotubes as multifunctional biological transporters and near-infrared agents for selective cancer cell destruction Proc. Natl. Acad. Sci. USA 10211600

12. Belloni F, Kutahyali C, Rondinella V, Carbol P and Wiss T 2009 Can carbon nanotubes play a role in the field of nuclear waste management? Environ. Sci. Technol. $\mathbf{4 3}$ 1250

13. Sessler J L, Melfi P J and Pantos G D 2006 Uranium complexes of multidentate N-donor ligands Coord. Chem. Rev. 250816 
14. Ye X, Cui S, de Almeida V F, Hay B P and Khomami B 2010 Uranyl nitrate complex extraction into TBP/dodecane organic solutions: A molecular dynamics study Phys. Chem. Chem. Phys. 1215406

15. Sengupta A, Mohapatra P K, Kadam R M, Manna D, Ghanty T K, Iqbal M, Huskens J, Verboom W (2014) Diglycolamide-functionalized task specific ionic liquids for nuclear waste remediation: Extraction, luminescence, theoretical and EPR investigations RSC Adv. 446613

16. Beer S, Berryman O B, Ajami D and Rebek Jr. J 2010 Encapsulation of the uranyl dication Chem. Sci. 143

17. Hu J, Chen C, Zhu X and Wang X 2009 Removal of chromium from aqueous solution by using oxidized multiwalled carbon nanotubes J. Hazard. Mater. 1621542

18. Moradi O, Zare K and Yari M 2011 Interaction of some heavy metal ions with single walled carbon nanotube Int. J. Nano Dimens. 1203

19. Ruparelia J P, Duttagupta S P, Chatterjee A K and Mukherji S 2008 Potential of carbon nanomaterials for removal of heavy metals from water Desalination 232 145

20. Atieh M A, Bakather O Y, Tawabini B S, Bukhari A A, Khaled M, Alharthi M, Fettouhi M and Abuilaiwi F A 2010 Removal of chromium (III) from water by using modified and nonmodified carbon nanotubes J. Nanomater. 1

21. Moradi O, Zare K, Monajjemi M and Aghaie H 2010 The studies of equilibrium and thermodynamic adsorption of $\mathrm{Pb}(\mathrm{II}), \mathrm{Cd}(\mathrm{II})$ and $\mathrm{Cu}(\mathrm{II})$ ions from aqueous solution onto SWCNTs and SWCNT-COOH surfaces Fullerenes Nanotubes Carbon Nanostruct. 18285

22. Thamavaranukup N, Hoppe H A, Ruiz-Gonzalez L, Costa P M F J, Sloan J, Kirkland A and Green M L H 2004 Single-walled carbon nanotubes filled with $\mathrm{M} \mathrm{OH}$ $(\mathrm{M}=\mathrm{K}, \mathrm{Cs})$ and then washed and refilled with clusters and molecules Chem. Commun. 1686

23. Wang $X$, Chen $\mathrm{C}$, Hu W, Ding A, Xu D and Zhou X 2005 Sorption of ${ }^{243} \mathrm{Am}$ (III) to multiwall carbon nanotubes Environ. Sci. Technol. 392856

24. Lan T, Wang H, Liao J, Yang Y, Chai Z, Liu N and Wang D 2016 Dynamics of humic acid and its interaction with uranyl in the presence of hydrophobic surface implicated by molecular dynamics simulations Environ. Sci. Technol. 5011121

25. Schierz A and Zanker H 2009 Aqueous suspensions of carbon nanotubes: Surface oxidation, colloidal stability and uranium sorption Environ. Pollut. 1571088

26. Kahn M G C, Banerjee S and Wong S S 2002 Solubilization of oxidized single-walled carbon nanotubes in organic and aqueous solvents through organic derivatization Nano Lett. 21215

27. Banerjee S and Wong S S 2002 Structural characterization, optical properties, and improved solubility of carbon nanotubes functionalized with Wilkinson's catalyst J. Am. Chem. Soc. 1248940

28. Li Z, Chen F, Yuan L, Liu Y, Zhao Y, Chai Z and Shi W 2012 Uranium(VI) adsorption on graphene oxide nanosheets from aqueous solutions Chem. Eng. J. 2012 210539

29. Jiang D, Liu L, Pan N, Yang F, Li S, Wang R, Wyman I W, Jin Y and Xia C 2015 The separation of Th(IV)/U(VI) via selective complexation with graphene oxide Chem. Eng. J. 271147

30. Luksirikul P, Ballesteros B, Tobias G, Moloney M $\mathrm{G}$ and Green M L H $2010 \mathrm{pH}$-triggered release of materials from single-walled carbon nanotubes using dimethylamino-functionalized fullerenes as removable "corks" Carbon 481912

31. Perevalov S A and Molochnikova N P 2009 Sorption of $\mathrm{Pu}$ in various oxidation states onto multiwalled carbon nanotubes J. Radioanal. Nucl. Chem. 281603

32. Gu Z, Wang Y, Tang J, Yang J, Liao J, Yang Y and Liu N 2015 The removal of uranium(VI) from aqueous solution by graphene oxide-carbon nanotubes hybrid aerogels $J$. Radioanal. Nucl. Chem. 3031835

33. Romanchuk A Y, Slesarev A S, Kalmykov S N, Kosynkinz D V and Tour J M 2013 Graphene oxide for effective radionuclide removal Phys. Chem. Chem. Phys. 152321

34. Wu Q Y, Lan J H, Wang C Z, Xiao C L, Zhao Y L, Wei Y Z, Chai Z F and Shi W Q 2014 Understanding the bonding nature of uranyl ion and functionalized graphene: A theoretical study J. Phys. Chem. A 1182149

35. Wu Q Y, Lan J H, Wang C Z, Zhao Y L, Chai Z F and Shi W Q 2014 Understanding the interactions of neptunium and plutonium ions with graphene oxide: Scalar-relativistic DFT investigations J. Phys. Chem. A 11810273

36. Balasubramanian K and Burghard M 2005 Chemically functionalized carbon nanotubes Small 1180

37. Sundararajan M and Ghosh S K 2011 Designing novel materials through functionalization of carbon nanotubes for application in nuclear waste management: Speciation of uranyl J. Phys. Chem. A 1156732

38. Jena N K, Sundararajan M and Ghosh S K 2012 On the interaction of uranyl with functionalized fullerenes: a DFT investigation RSC Adv. 22994

39. Sundararajan M 2013 Designing novel nanomaterials through functionalization of carbon nanotubes with supramolecules for application in nuclear waste management Sep. Sci. Technol. 482391

40. Blöchl P E 1994 Projector augmented-wave method Phys. Rev. B 5017953

41. Kresse G and Joubert D 1999 From ultrasoft pseudopotentials to the projector augmented-wave method Phys. Rev. B 591758

42. Kresse G and Joubert D 1996 Efficiency of ab-initio total energy calculations for metals and semiconductors using a plane-wave basis set Comput. Mater. Sci. 615

43. Kresse G and Joubert D 1996 Efficient iterative schemes for ab initio total-energy calculations using a plane-wave basis set Phys. Rev. B 5411169

44. Perdew J P, Burke K and Ernzerhof M 1996 Generalized gradient approximation made simple Phys. Rev. Lett. 77 3865

45. Monkhorst H J and Pack J D 1976 Special points for Brillouin-zone integrations Phys. Rev. B 135188

46. Tang W, Sanville E and Henkelman G 2009 A grid-based Bader analysis algorithm without lattice bias Condens. Matter. 21084204

47. Sanville E, Kenny S D, Smith R and Henkelman G 2007 Improved grid-based algorithm for Bader charge allocation J. Comput. Chem. 28899 
48. Henkelman G, Arnaldsson A and Jónsson H 2006 A fast and robust algorithm for Bader decomposition of charge density Comput. Mater. Sci. 36254

49. Srinivasu K, Modak B and Ghosh S K 2014 Porous graphitic carbon nitride: A possible metal-free photocatalyst for water splitting J. Phys. Chem. C 11826479

50. Sun Y Y, Lee K, Kim Y H and Zhang S B 2009 Ab initio design of Ca-decorated organic frameworks for high capacity molecular hydrogen storage with enhanced binding Appl. Phys. Lett. 95033109

51. Austin J P, Sundararajan M, Vincent M A and Hillier I H 2009 The geometric structures, vibrational frequencies and redox properties of the actinyl coordination complexes $\left(\left[\mathrm{AnO}_{2}(\mathrm{~L})_{\mathrm{n}}\right]^{\mathrm{m}} ; \mathrm{An}=\mathrm{U}, \mathrm{Pu}, \mathrm{Np} ; \mathrm{L}=\mathrm{H}_{2} \mathrm{O}\right.$, $\mathrm{Cl}^{-}, \mathrm{CO}_{3}^{2-}, \mathrm{CH}_{3} \mathrm{CO}_{2}^{-}, \mathrm{OH}^{-}$) in aqueous solution, studied by density functional theory methods Dalton Trans. 5902

52. Clark D L, Conradson S D, Donohue R J, Keogh D W, Morris D E, Palmer P D, Rogers R D and Tait C D 1999 Chemical speciation of the uranyl ion under highly alkaline conditions. Synthesis, structures, and oxo ligand exchange dynamics Inorg. Chem. 381456

53. Aberg M, Ferri D, Glaser J and Grenthe I 1983 Structure of the hydrated dioxouranium(VI) ion in aqueous solution. An X-ray diffraction and proton NMR study Inorg. Chem. 223986

54. Mentzen B F 1977 The crystal structure of sodium uranyl triformate monohydrate, $\mathrm{NaUO}_{2}(\mathrm{HCOO})_{3} \cdot \mathrm{H}_{2} \mathrm{O}$ Acta Cryst. B33 2546

55. Jiang J, Rao L, Di Bernardo P, Zanonato P L and Bismondo A J 2002 Complexation of uranium(VI) with acetate at variable temperatures J. Chem. Soc., Dalton Trans. 81832

56. Rogachev A Y, Filatov A S, Zabula A V and Petrukhina M A 2012 Functionalized corannulene cations: A detailed theoretical survey Phys. Chem. Chem. Phys. 12 3554

57. Gelis A V and Lumetta G J 2014 Actinide lanthanide separation process-ALSEP Ind. Eng. Chem. Res. 53 1624 